\title{
Cloud-based software development and implementation using SAP for teacher attendance monitoring
}

\author{
Alexi Delgado ${ }^{1}$, Estefo Tume Humberto ${ }^{2}$, Chiara Carbajal ${ }^{3}$ \\ ${ }^{1}$ Mining EngineeringSection, Pontificia Universidad Católica del Perú, Lima-Peru, kdelgadov@ pucp.edu.pe \\ ${ }^{2}$ Systems EngineeringProgram, Universidad de Ciencias y Humanidades, Lima-Peru, humestefot @ uch.pe \\ ${ }^{3}$ Administration Program, Universidad de Ciencias y Humanidades, Lima-Peru, ccarbajal@uch.edu.pe
}

\begin{abstract}
In Peru, unpunctuality or regular absences by university teachers during class hours contribute to a deficient educational system for the population. In response to this, this paper developed the coding method in conjunction with SAP tools, having simple specific activities and an order in them. The aim of this is to develop a web system that allows an adequate registration and monitoring of the attendance of the professor during classes in the universities of Lima, Peru. The web system has been applied at the University of the Americas (UDLA-Ecuador), contributing to the control of teacher attendance. These results show that the software is effective and efficient for future application in the universities of Lima, since it will allow the control of the teacher's attendance in an optimal way.
\end{abstract}

Key words :Cloud application, Mobile Application, SCP application, Teaching assistance.

\section{INTRODUCTION}

The New Zealand Productivity Commission has shown that although one works longer hours, it does not necessarily imply that one works better [1]. Nevertheless, there are organizations that demand minimum working hours from their employees and expect them to be punctual [2]. This paper does not discuss the relationship between working hours and productivity, but emphasizes that this imposition is essential, especially in the case of educational institutions, since it highlights the importance of the relationship between student learning and the time given by the professor. The reason for this is that in order to ensure the quality of teaching, the least that is required for proper learning is the assistance of the university professor [3]. Otherwise, students associate the lack of punctuality and attendance of the teacher with a lack of responsibility and respect for the students [4], which affects their level of interest in the class, which leads to damage to their own learning. Therefore, although there are possibilities for regulating student attendance, it is necessary to start with teachers [5].
In this way, it is clear that there must be a means to effectively record and control attendance, whether in physical or digital form, and that it must allow security measures to be taken to avoid possible alteration, deterioration or loss [6]. However, while many educational institutions opt for manual physical recording for attendance control, they must subsequently enter it into a computer system in order to generate reports, which makes it a laborious process and increases the workforce's requirements [7]. A responsive web-based system has been proposed with $\mathrm{QR}$ reader capabilities to record teacher attendance in the classroom directly, avoiding downtime, in the city of Lima, Peru. This web system will also be able to evaluate the impact of the economic incentive system on teachers' monthly and annual attendance patterns [8], since the educational institution will be able to sanction academic tardiness.

For the development of this web system, which has already been implemented at the Universidad de las Américas (UDLA) in Ecuador, it has been decided to use the Build.Me tool, with the purpose of designing the prototype, since the tool allows access not only to the Frontend and Backend, but also to the database [9]. Subsequently, the web system will be developed in SAP HCP as it is focused on integrating the applications in the cloud and in the facilities seamlessly [10]. Likewise, SAP S/4 HANA will allow the IT landscape objectives to be met with hybrid scenarios [11], an advantage that will be used to create a responsive web system for adaptation to mobile.

Therefore, the aim of this research is to design and implement a responsive web system that allows users (university professors in this case) to register their attendance in their class schedule with an online database.

The present work is divided in the following way: Section 2 will explain the methodology and tools to be used. Section 3 will cover the application of the case study. Section 4 will develop the results and discussions; and section 5 will detail the conclusions obtained.

\section{METHODOLOGY}

The methodology of this research will be carried out for the development and implementation of the web application system. In the design of the application it will be possible to locate the Build.Me tool. On the other hand, as far as the 
application is concerned, a responsive web system will be created, which indicates that it can be used both on the web and on cell phones, the latter being accessed through an URL. At this point the SAP tools will be used. The tools to be used are explained below.

\subsection{SAP}

SAP or "Systems, Applications, Products in Computer Science", is a computing system which permits enterprises to administer and manage human resources, financial-accounting, productivity, logistics and more [12]. It has many years of experience supplying stock planning solutions to its clients, either natively as part of SAP Supply Chain Management (SAP SCM) or through third party suppliers [13].

\subsection{SAP UI5}

SAP UI5 supports the development and layout of HTML5-based, business-responsive SAP web applications. It is a programming framework that facilitates the development of web applications; therefore, the UI5 core offers a solid base that simplifies your work by managing many aspects of modern behind-the-scenes development [14].

\subsection{SAP S4 Hana}

This tool marks a step beyond the Data Logging Transaction System. It shows us that it is the exclusive database of SAP ERP and SAP Business Suite.

\subsection{SAPHana Cloud Platform}

SAP HCP is a service platform, which means to use SAP UI5, in conjunction with SAP S4 HANA. Because it is an open business platform designed to help innovate, integrate and extend applications with agility, flexibility and variety [15].

\subsection{Build.Me}

Build.Me is a comprehensive SAP tool with a catalogue of Fiori prototypes to reference as well as to remix in order to match final customers' necessities [16]. By catalogue, it refers to defined prototype sketches, in this particular case for a responsive web application, which allows us to operate and design.

\section{A. Advantages}

It allows stakeholders and users to visualize the design and assist in shaping the front-end before any development begins.

\section{B. Disadvantages}

The components are limited for all the tools that SAP UI5/ Fiori has. The canvas is dynamic, but sometimes it does not set the components well so the page must be refreshed.

\subsection{HTML}

HTML is a software reference standard for connecting web pages. In this work HTML 5 will be used specifically, being this the fifth revision of the HTML language, and it is one of the most important factors for this project since it is used for the elaboration of web pages.

\subsection{JavaScript}

JavaScript is a programming language for the web [17]. This indicates that JavaScript is an interpreted language and that it is implemented as part of a web browser allowing to improve the interface and at the same time to make the web pages dynamic.

\section{APPLICATION}

\subsection{Prototype Design}

Build.Me provided all the components and elements to make web applications, giving us the tools that are more efficient, also allowed unrestricted access to the components of SAPUI5 Fiori. Build.Me was able to create all the views and the flow that the application will follow; meaning, the login sequence to enter the university professor's personal account, followed by the QR codes for entering and exiting the classes; likewise, it was considered to access the students' notes for a more accessible data visualization, as an addition to the web system, as can be seen in Figure 1.

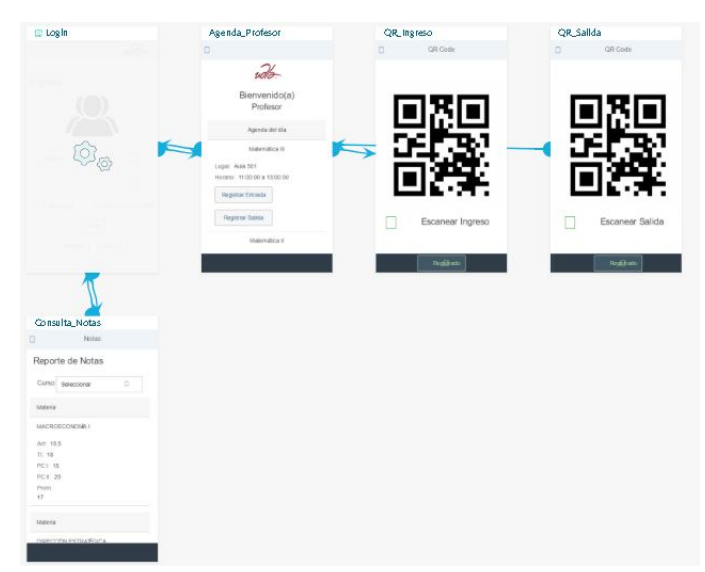

Figure 1: Creation of views and flow through Build.Me

\subsection{Development of Web System for Teachers}

For the purpose of recording teacher attendance, SAP HCP was used, which contains the tools HTML 5, SAP UI5, SAP S4 HANA and JavaScript, to create the main views such as the $\log$ and login to the institution, as shown in Figure 2. Once the login is made, the teacher's class schedule information screen will be accessed, as well as their respective classrooms, as shown in Figure 3.

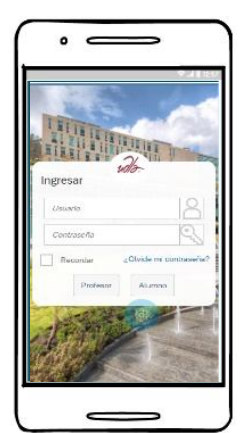

Figure 2: $\log$ in Screen

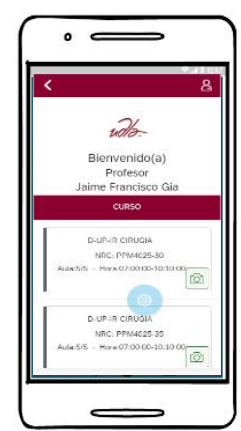

Figure 3: Class Schedule 
Further details of the user functions in the application (i.e. referred to in Figure 3) are given in Table 1.

Table 1:Functionality of the server for the teacher

\begin{tabular}{|c|l|}
\hline Function & \multicolumn{1}{c|}{ Description } \\
\hline Schedule & $\begin{array}{l}\text { It shows the time of entry into a respective } \\
\text { classroom. }\end{array}$ \\
\hline Classroom & $\begin{array}{l}\text { The user will be able to see in which room } \\
\text { he has his following lecture. }\end{array}$ \\
\hline Course Code & $\begin{array}{l}\text { Functionality that allows differentiation } \\
\text { from other courses, according to the } \\
\text { curriculum of the institution. }\end{array}$ \\
\hline QR Reader & $\begin{array}{l}\text { Its main function is to read the QR code } \\
\text { and mark the teacher's attendance when he } \\
\text { or she enters and leaves the corresponding } \\
\text { session. }\end{array}$ \\
\hline
\end{tabular}

Figure 4 shows the layout screen of the main functionality of the QR code set to the scanned classroom entry option.

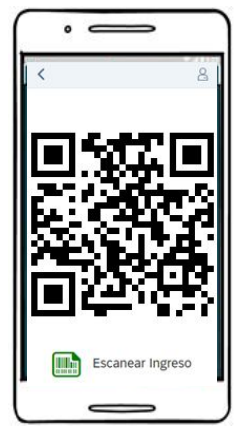

Figure 4: QR Code Reader

\subsection{Development of Web System for Classrooms}

At this phase the Web System will be developed to generate the QR code that will read the system for teachers as shown in Figure 5.

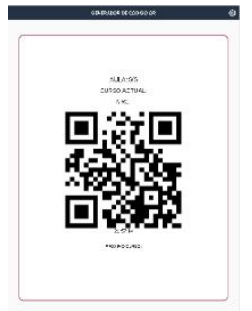

Figure 5: QR Code Generator

\section{RESULTS AND DISCUSSION}

This system proposal has been implemented at Universidad de las Américas (UDLA) in Ecuador, since a new method was required to control the attendance of its professors, due to their usual lack of punctuality and presence. Thus, the professor of the mentioned university marked attendance twice, the first time in a traditional way thanks to the employee card that identify him, on the door as seen in Figure 6. Following this, once found in the classroom (Figure 7), attendance was marked through the execution of the implemented web system. The final results showed positive indicators demonstrating the benefit that the system obtained in its application.

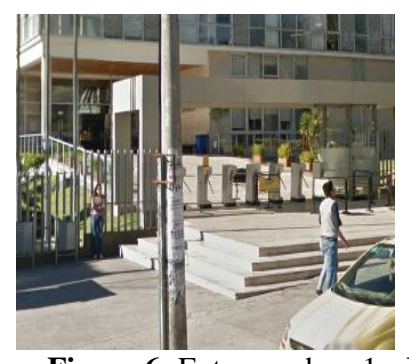

Figure 6: Entrance door 1 UdlaPark Headquarter

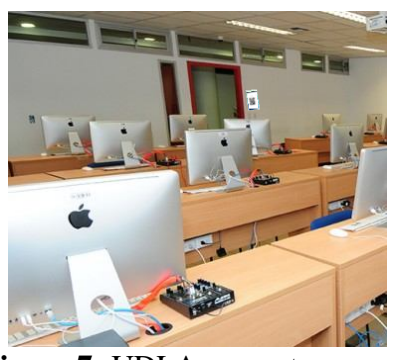

Figure 7: UDLA computer room Granados Headquarter

\subsection{About the Application}

It has been evaluated that, unlike a previous study [7], this research does not require an Arduino board or external circuits, which evidences its practicality by requiring only a smartphone, which is already common among university professors, and a tablet that allows registration in the classroom. A similar situation is compared with the study by J. Iio[18], which requires a card reader.

\subsection{About the Methodology}

The main advantage of the methodology and tools used in this research article is the dynamism when carrying out the project, since SAP tools are in the cloud and allow programming without the need for downloading programs.

\section{CONCLUSIONS}

In this paper a software to record attendance at the University of Ecuador was designed and implemented. The efficiency of the system demonstrated serves as a basis for proposing a web system similar to the present in the universities of Lima, Peru, in order to combat the unpunctuality and non-attendance of university professors in classes, which will benefit student quality.

Regarding the tools chosen, the SAP Cloud Platform permitted a dynamic and interactive development, as well as direct access to the cloud; which benefited the proposal, since it was allowed to be in real time at a fast response speed without saturation of the system.

Lastly, it is highly anticipated that the results will serve as a foundation for any educational institution seeking to optimize the monitoring and control of university faculty attendance in their classrooms. Likewise, it is suggested that, although the educational institution decides the actions to be taken in case of delay or non-attendance, future research could recommend an approximate discount to teachers as a constructive penalty that will promote in a certain way the attendance of educators.

\section{REFERENCES}

1. C.W. and A.J.K.D., Working hours: Get a life | The Economist, Economist, vol. 280, no. 5365, pp. 849-850, 2013. 
2. M. A. Rasyidi, Dissecting university employee attendance log: A case study, in Proceeding - 2017 3rd International Conference on Science in Information Technology: Theory and Application of IT for Education, Industry and Society in Big Data Era, ICSITech 2017, 2017, vol. 2018-January, pp. 593-597.

3. A. A. Winkler and A. Carril Rubio, Impacto a corto plazo del absentismo docente en el desempeño escolar chileno, Universidad de Chile, 2015.

4. J. M. García Garduño and A. Medécigo Shej, Los criterios que emplean los estudiantes universitarios para evaluar la in-eficacia docente de sus profesores, Perfiles Educ., vol. 36, no. 143, pp. 124-139, Dec. 1969. https://doi.org/10.1016/S0185-2698(14)70613-0

5. L. Morales Ríos, La inasistencia a causa de costumbres y tradiciones en la comunidad indígena Purepecha de Ahuiran Michoacan en el nivel de preescolar, Prax. Investig. ReDIE Rev. electrónica la Red Durango Investig. Educ., vol. 5, no. 9, pp. 30-42, 2013.

6. G. Infantes, R. Mucha, and B. Egúsquiza, Manual de obligaciones del empleador y beneficios del trabajador. Lima, Perú, 2012.

7. D. Sunehra and V. S. Goud, Attendance recording and consolidation system using Arduino and Raspberry $\mathbf{P i}$, in International Conference on Signal Processing, Communication, Power and Embedded System, SCOPES 2016 - Proceedings, 2017, pp. 1240-1245.

8. S. Cueto, M. Torero, J. León, and J. Deustua, Asistencia docente y rendimiento escolar: el caso del programa META 1.

9. SAP, SAP Fiori - SAP Help Portal Page, 2013. [Online]. Available: https://help.sap.com/viewer/acb8ee53fa0e448f9b4a4125 591f5d5a/Cloud/en-US/b02f509d805e428e9b282af4363 8312c.html. [Accessed: 14-Jan-2020].

10. Overview | SAP Cloud Platform. [Online]. Available: https://cloudplatform.sap.com/index.html. [Accessed: 14-Jan-2020].

11. SAP S/4HANA ERP | In Memory Business Suite. [Online]. https://www.sap.com/products/s4hana-erp.html. [Accessed: 14-Jan-2020].

12. D. Soto, ¿Qué es SAP y para que sirve?, Next Tech, 2017. [Online]. Available: https://nextech.pe/que-es-sap-y-para-que-sirve-sap/. [Accessed: 16-Jan-2020].

13. S. Markin and A. Sinha, SAP Integrated Business Planning : functionality and implementation, Second. Boston: Rheinwerk Publishing, 2018.

14. Home - Demo Kit - SAPUI5 SDK. [Online]. Available: https://sapui5.hana.ondemand.com/\#. [Accessed: 14-Jan-2020].

15. ¿Qué es SAP S/4HANA? 13 preguntas contestadas SAP News Center Latinoamérica. [Online]. Available: https://news.sap.com/latinamerica/2015/05/que-es-sap-s 4hana-13-preguntas-contestadas/. [Accessed: 14-Jan-2020].

16. Build beautiful apps | BUILD.me. [Online]. Available: https://www.build.me/. [Accessed: 14-Jan-2020].
17. What is JavaScript. [Online]. Available: https://www.w3schools.com/whatis/whatis_js.asp. [Accessed: 14-Jan-2020].

18. J. Iio, Attendance Management System Using a Mobile Device and a Web Application, in NBiS 2016 19th International Conference on Network-Based Information Systems, 2016, pp. 510-515. 